\title{
SHOUld the Law Governing Maritime AREAS IN THE Arctic Adapt to Changing Climatic Circumstances?
}

\author{
ERIK FRANCKX*
}

The legal regime of the Arctic maritime areas has long remained on the backburner as far as the creation of multilateral agreements is

* Research Professor, President of the Department of International and European Law and Director of the Centre for International Law at the Vrije Universiteit Brussel (V.U.B.; Pleinlaan 2, B-1050, Brussels, Belgium; Erik.Franckx@vub.ac.be). He holds teaching assignments at the Vesalius College (V.U.B.), Université Libre de Bruxelles, the Brussels School of International Studies (University of Kent at Canterbury), the Program on International Legal Cooperation (Institute of European Studies, V.U.B.), and the Universite Paris-Sorbonne Abu Dhabi. He has been appointed by Belgium as a member of the Permanent Court of Arbitration, The Hague, The Netherlands; as an expert in marine scientific research for use in special arbitration under the 1982 United Nations Convention on the Law of the Sea; as a legal expert in the Advisory Body of Experts of the Law of the Sea of the Intergovernmental Oceanographic Commission of the United Nations Educational, Scientific and Cultural Organization; and as an expert in maritime boundary delimitation to the International Hydrographic Organization.

The author would first of all like to express his gratitude to Springer for having allowed the reproduction of this Article, which first appeared as Erik Franckx, Should the Law Governing Maritime Areas in the Arctic Adapt to Changing Climatic Circumstances?, in CLIMATE GOVERNANCE IN THE ARCTIC 119 (Koivurova, Timo; Keskitalo, E. Carina H.; Bankes, Nigel eds., 2009). It later also appeared, updated, in French in Erik Franckx, L'Arctique. Du changement climatique au changement juridique?, in L'ÉVOLUTION ET L'ÉTAT ACTUEL DU DROIT INTERNATIONAL DE LA MER. MÉLANGES DE DROIT DE LA MER OFFERTS À DANIEL VIGNES 299 (Raefael Casado Raigon \& Guiseppe Cataldi, eds., 2009).

Secondly, the author is also indebted towards California Western School of Law, where he was appointed as Castetter Visiting Foreign Law Professor between March 10 and April 20, 2008. During that period, he gave a number of lectures, one of which was for the faculty on the following topic: "Is the Arctic (Legally) Heating Up?" Part of the research for the present Article was undertaken during that period.

Since Springer required a lead period for publication in a journal, this explains why the present Article is only published now, but with a status iuris located at the end of 2008. A post-scriptum has, however, been added. 
concerned. The Arctic's inhospitable climate created natural barriers for the activities of man and limited the usefulness of available technology. At present, however, climate change seems to be responsible for a marked heating up, ${ }^{1}$ not only of the physical environment of the Arctic, but of the political tensions concerning the exact legal regime to be applied in the region.

This Article will examine the present-day legal status of the Arctic. Since almost all territorial claims have been settled in the area, ${ }^{2}$ only Arctic water areas will retain our attention. And, within the

1. Or moving the issue "to the front burner again before long" as predicted by one author. Jeremy Kinsman, Who is My Neighbour? Trudeau and Foreign Policy, 57 INT'L J. 57, 66 (2001).

2. The only outstanding issue at present as far as land territory is concerned appears to be Hans Island. See, e.g., Donald McRae, Arctic Sovereignty? What is at Stake?, 64 BEHIND THE HEADLINES 1, 3 (2007). Hans Island, less than a mile in length north to south, is located midway between Greenland and Ellesmere Island in Kennedy Channel at $80^{\circ} 49^{\prime}$ N. In 1973, when Denmark and Canada delimited their maritime boundary in the area, Agreement Relating to the Delimitation of the Continental Shelf Between Greenland and Canada, Den.-Can., Dec. 17, 1973, 950 U.N.T.S. 147, neither side appeared willing to press the issue of sovereignty over the island.

As a result, the delimitation in the area surrounding the island was left undetermined, Canada-Denmark (Greenland): Report Number 1-1, in 1 INTERNATIONAL MARITIME BOUNDARIES 371, 372 (Jonathan I. Charney \& Lewis M. Alexander eds., 1993), and is still contested today. See generally Christopher Stevenson, Hans Off!: The Struggle for Hans Island and the Potential Ramifications for International Border Dispute Resolution, 30 B.C. INT'L \& COMP. L. REV. 263 (2007). Whether Wrangel and a few other Arctic islands located off the northern far eastern coast of Russia have to be mentioned here is less clear. ERIK FRANCKX, MaRitime Claims IN the ARCTIC: CANAdian AND Russian PERSPECTIVES 143-44 (1993) (analyzing the issue in relation to the 1990 maritime boundary agreement between the former Soviet Union and the United States); Agreement on the Maritime Boundary, U.S.-U.S.S.R., June 1, 1990, 17 LAW OF THE SEA BULL. 15 (provisionally entered into force June 15, 1990). On December 23, 1994, the Supreme Court of Alaska finally dismissed - based on the following argument-a later claim introduced by an individual wanting to register his interests in five of these islands in the Nome Recording District:

The question of sovereignty over the Arctic Islands is a subject committed to the executive and legislative branches of the United States government. ... . Until and unless the United States government indicates that the Arctic Islands are part of the State of Alaska, the State has no duty to accept for recording documents affecting title to real property on the islands.

Denardo v. State, 887 P.2d 947, 949 (Alaska 1994) (citations omitted). 
multitude of possible offshore activities, this Article will focus solely on navigation. Part I discusses the 1982 United Nations Convention on the Law of the $\mathrm{Sea}^{3}{ }^{3}$ which seems to have finally become a generally accepted legal cornerstone for appreciating the legal status of these waters. Part II considers climate change in the Arctic and Part III elaborates on how this may impact the legal regime of navigation there. Subsequently, Part IV analyzes the vulnerability as well as the adaptive capacity of the 1982 Convention. Finally, Part V suggests how the existing legal system can better meet the new challenges climate change poses for Arctic water expanses.

\section{THE 1982 CONVENTION}

In contrast to the Antarctic, where international cooperation has formed the essence of the development of a very specific international legal regime applicable in the area, as evidenced in a good number of international agreements, the Arctic generally lacks such an integrated and comprehensive regime based on regional multilateral cooperation. ${ }^{4}$ Moreover, it is startling to see that the polar bear, which triggered the conclusion of the first multilateral instrument joining all five Arctic rim countries, ${ }^{5}$ has become the face of the campaign trying to stop climate change in the Arctic. This implies that if this quest to

A 2003 statement published by the U.S. Department of State, Bureau of European and Eurasian Affairs seems to indicate that the government has no such intention, for it states that these islands have never been claimed by the United States. Fact Sheet, U.S. Dep't of State, Status of Wrangel and Other Arctic Islands (May 20, 2003). A recent review of the question by Russian scholars comes to the conclusion that these claims find no basis in international law. Russian sovereignty, they argue, is widely recognized and based on prolonged possession. Egorov, N. P., Kolodkin, A. L., Mikhina, I. N. \& Vylegzhanin, A. N., Pravovoi Rezhim Sudokhodstva $v$ Arktiki [The Legal Regime of Navigation in the Arctic], in Problemy SEVERNOGo MORSKOGO PUTI 482, 489-90 (Alexander G. Granberg \& Vladimir I. Peresypkin eds., 2006).

3. U.N. Convention on the Law of the Sea, opened for signature Dec. 10 , 1982, 1833 U.N.T.S. 397 (entered into force Nov. 16, 1994) [hereinafter 1982 Convention].

4. See Donald R. Rothwell, The Polar Regions and the Development OF INTERNATIONAL LAW 221 (1996).

5. See Agreement on the Conservation of Polar Bears, Nov. 15, 1973, 13 I.L.M. 13 (entered into force on May 26, 1976). The parties to this agreement are: Canada, Denmark, Norway, Russian Federation and United States of America. Id. 
400 California Western InTERnational LaW JournaL [Vol. 41

stop climate change were to be unsuccessful, ${ }^{6}$ one of the few hard law instruments specifically conceived of for the Arctic will disappear together with its object, the polar bear. The preferred method of regional cooperation in the Arctic has recently been coined "soft sleddings," a process expected to continue during the next decade. And no matter how significant this "mosaic of cooperative arrangements" might be, ${ }^{8}$ binding hard law instruments remain an Arctic rarity.

This does not mean that the Arctic is a free for all, located beyond the confines of international law. ${ }^{9}$ On the contrary, a clear tendency can be discerned during the last decade or so toward a common acceptance by countries in general, and more importantly the Arctic rim countries in particular, that the 1982 Convention contains the generally applicable legal framework in the area.

First of all, this latter tendency has to do with states' attitudes toward the instrument itself. The 1982 Convention, envisioned to

6. In the United States, the struggle to protect the polar bear focuses at present on the bear's listing as a threatened species under the Endangered Species Act. See generally Brendan R. Cummings \& Kassie R. Siegel, Ursus Maritimus: Polar Bears on Thin Ice, 22 NAT. RESOURCES \& ENV'T. 3 (2007); Laura Navarro, What About the Polar Bears? The Future of the Polar Bears as Predicted by a Survey of Success under the Endangered Species Act, 19 VILL. ENVTL. L.J. 169 (2008); Justin Olsson, The Future of the Polar Bear Rests on Thin Ice: Listing Under the ESA and its Impacts, 8 SUSTAINABLE DEV. L. \& POL'Y 46 (2007); Nigel Bankes, Climate Change and the Regime for the Conservation of Polar Bears, in CLIMATE GOVERNANCE IN THE ARCTIC, supra note *, at 351.

7. Timo Koivurova \& David L. VanderZwaag, The Arctic Council at 10 Years: Retrospect and Prospects, 40 U.B.C. L. REV. 121, 191 (2007).

8. Oran R. Young, Governing the Arctic: From Cold War Theater to Mosaic of Cooperation, 11 GLOBAL GOVERNANCE 9, 14 (2005).

9. This idea is sometimes implied in recent analyses of this issue. See, e.g., Scott G. Borgerson, Arctic Meltdown: The Economic and Security Implications of Global Warming, 87 FOREIGN AFFAIRS 63, 74 (2008) (calling the Arctic a "legal no man's land"). After having stated that the Arctic is "not currently governed by any comprehensive multilateral norms and regulations," and affirmed that "there are currently no overarching ... . legal structures that can provide for the orderly development of the region," the author subsequently mentions the 1982 Convention, which, according to him, "cannot be seamlessly applied to the Arctic." Id. at 65, 7172. But, all the examples given to prove this latter point, namely the division of the continental shelf, regime of navigation, maritime boundary delimitation, and the issue of flags of convenience, are all elements that this convention addresses either directly, or by reference to other competent international organizations. $I d$. at 72 . 
become the Constitution for the Oceans,${ }^{10}$ seems well on its way to achieving that status. ${ }^{11}$ Moreover, when focusing on the Arctic rim countries proper, it appears that while Norway and the Russian Federation ratified that convention during the second half of the $1990 \mathrm{~s},{ }^{12}$ Canada and Denmark did so only more recently. ${ }^{13}$ None of these countries included a direct reference to the Arctic in any of their declarations made upon signature or ratification. ${ }^{14}$ As of today, the United States is the only Arctic rim country that is not yet a party to the 1982 Convention, despite the recent presidential initiative in this

10. Conference Report, Third United Nations Conference on the Law of the Sea A Constitution for the Oceans, , (Dec. $6 \& 11,1982$ ) (statement of Tommy T.B. Koh, Pres. of Third U.N. Conf. on Law of the Sea), http://www.un.org/Depts/los/convention_agreements/texts/koh_english.pdf.

11. At the time of this writing, 154 states and the European Union are bound by this legal instrument. United Nations, Chronological Lists of Ratifications of, Accessions and Successions to the Convention and the Related Agreements, http://www.un.org/Depts/los/reference_files/chronological_lists_of_ratifications.htm (last updated Nov. 15, 2010).

12. These countries ratified the 1982 Convention on June 24, 1996 and March 12,1997 , respectively. United Nations Div. for Ocean Affairs and the Law of the Sea, Status of the United Nations Convention on the Law of the Sea, of the Agreement Relating to the Implementation of Part XI of the Convention, and of the Agreement for the Implementation of the Provisions of the Convention Relating to the Conservation and Management of Straddling Fish Stocks and Highly Migratory Fish Stocks (Nov. 30, 2010), http://www.un.org/Depts/los/reference_files/ status2010.pdf.

13. Namely on November 7, 2003, and November 16, 2004, respectively. Id.

14. Given its particular importance with respect to the Arctic, it might nevertheless be appropriate to highlight the fact that the Russian Federation specifically inserted between "sea boundary delimitations" and "disputes concerning military activities," (both excluded on the basis of Article 298, Section (1)(a)(i) ["Art. 298 (1)(a)(i)"] of the 1982 Convention in its declaration made at the time of signature) "historic bays or titles" when rephrasing its declaration at the time of ratification. United Nations, Declarations and Statements (2010), http://www.un.org/Depts/los/convention_agreements/convention_declarations.htm [hereinafter U.N. Declarations]. Also, this latter addition, it should be noted, is in full conformity with the provision of Art. 298 (1)(a)(i). See 1982 Convention, supra note 3, at art. 298(1)(a)(i). Canada also included "historic bays or titles" in its list of exclusion at the time of ratification. Although not exclusively linked to the Arctic, it might be noted that both countries also added delimitation issues to the list, as provided by the same article. See U.N. Declarations, supra. 
respect. ${ }^{15}$ It is noteworthy that the Arctic ranks high on the agenda of some authors who presently want to speed up this process. ${ }^{16}$ Nevertheless, this absence of ratification by one of the major actors in the region does not put into question the tendency toward common acceptance of the 1982 Convention as the generally applicable legal framework in the area, as the United States has always agreed to abide by the vast majority of the provisions of the 1982 Convention $^{17}$ and clearly considered this agreement to govern the Arctic as well. ${ }^{18}$

Secondly, the 1982 Convention seems to have become the quintessential document when scholars address the legal regime of the Arctic. ${ }^{19}$ Especially since Canada and the Russian Federation-the

15. The road followed by the United States to the ratification of the 1982 Convention has been a tortuous one indeed. See, e.g., David D. Caron \& Harry N. Scheiber, The United States and the 1982 Law of the Sea Treaty, INSIGHTS, June 11, 2007, available at http://asil.org/insights/2007/06/insights070611.html; see also John E. Noyes, U.S. Policy and the United Nations Convention on the Law of the Sea, 39 GEO. WASH. INT'L L. REV. 621 (2007).

16. See, e.g., Candace L. Bates, Comment, U.S. Ratification of the U.N. Convention on the Law of the Sea: Passive Acceptance Is Not Enough to Protect U.S. Property Interests, 31 N.C. J. INT'L L. \& COM. REG. 745, 767, 779-80 (2006). See generally Andrew King, Comment, Thawing a Frozen Treaty: Protecting United States Interests in the Arctic with a Congressional-Executive Agreement on the Law of the Sea, 34 HASTINGS CONST. L.Q. 329 (2007).

17. This occurred when the United States proclaimed an exclusive economic zone. See United States: Proclamation on an Exclusive Economic Zone, Mar. 10, 1983, 22 I.L.M. 461. The President seized the occasion to make a much broader statement on the U.S. oceans policy in general, in which he clearly indicated that, besides Part XI (The Area), the United States was prepared to accept the conventional rules on the basis of reciprocity. Id. at 464-65 (statement of Ronald Reagan, President of the United States).

18. A map accompanying the 1983 Proclamation, for instance, included the Arctic in the area of application of this novel concept. Id. at 463 (detailing a "[s]ketch map showing approximate outlines of Exclusive Economic Zone of the United States, Commonwealth of Puerto Rico, Commonwealth of the Northern Mariana Islands and United States overseas possessions.").

19. Hans Corell, the former Under-Secretary-General for Legal Affairs and the Legal Counsel of the United Nations, stressed this point at several recent occasions when discussing the legal regime of the Arctic. See, e.g., Hans Corell, Former Under Sec'y Gen. for Legal Affairs and the Legal Counsel of the United Nations, Address at the Seventh Conference of Parliamentarians of the Arctic Region, Reflections on the Possibilities and Limitations of a Binding Legal Regime for the Arctic 3 (Aug. 3, 2006) (transcript available at http://www.arcticparl.org/_res/ site/File/ static/conf7_hans_corell.pdf) ("The title of my presentation is framed in a 
two gate holders of the Northwest and Northeast Passage, respectively - have become parties to this convention, ${ }^{20}$ legal scholars in these two countries tend to found their legal analyses on this particular document. All recent articles, mentioned in this Article and written by Canadian authors, rely on the 1982 Convention for at least some part of their argumentation. ${ }^{21}$

With respect to Soviet authors, this latter tendency is even more remarkable. A careful analysis of Soviet and Russian doctrine up to the summer of 1992 reveals that in the late 1980s some changes occurred in the writings of Soviet jurists. With respect to the sector principle, for instance, the broad reading of the $1926 \mathrm{Decree}^{22}$ (subsuming water areas to be included in a decree that only explicitly mentioned lands and islands), ${ }^{23}$ was later mitigated by Soviet writers. Indeed, writings started to deny that the so-called lateral sector lines

manner that seems to suggest that there is no binding legal regime for the Arctic. But the fact is that there is already a wide-ranging legal regime that applies there, in particular the [1982 Convention].").

20. See supra notes 12-13 and accompanying text.

21. For some outspoken recent examples, see, for instance, McRae, supra note 2, at 4 ("The basic framework for the oceans is set out in the 1982 Convention on the Law of the Sea, to which Canada is a party, although the treaty provisions of that Convention are also intertwined with principles of customary international law, a matter that is particularly important when dealing with the United States, which has yet to become party to the 1982 Convention.") and Gillian MacNeil, Comment, The Northwest Passage: Sovereign Seaway or International Strait? A Reassessment of the Legal Status, 15 DALHOUSIE J. LEGAL STUD. 204, 217 (2006) ("[A]s Canada is a party to [the 1982 Convention], the treaty provisions are the logical place to begin an examination of the validity of its position over the Northwest Passage in International law.").

But even if no such explicit recognition is attributed to the 1982 Convention, as for instance in the authoritative recent article of Professor Pharand, it is clear that Pharand very much relies on its provisions either to confirm their application or to argue why Canada is sometimes believed to be exonerated from their application. See generally Donat Pharand, The Arctic Waters and the Northwest Passage: A Final Revisit, 38 OCEAN DEV. \& INT'L LAW 3 (2007).

22. On the Proclamation of Lands and Islands Located in the Northern Arctic Ocean as Territory of the U.S.S.R., April 15, 1926, reprinted in N. D. KOROLEVA, V. I. MARKov, AlEXANDER P. USHAKOV. PRAVOVOI REZHIM SUDOCHODSTVA V ROSSIISKOI ARKTIKE [LEGAL REGIME OF NAVIGATION IN THE RUSSIAN ARCTIC] 105 (1995) [hereinafter 1926 Decree] (containing both the Russian text and English translation).

23. See generally FRANCKX, supra note 2, at 152-53. 
constituted state boundaries, but still always mentioned the 1926 Decree when discussing the legal status of Arctic maritime areas. ${ }^{24}$ If one browses through the Russian doctrine between 1998 and 2008 , one could note further developments in this respect. ${ }^{25}$ The recently published, authoritative textbook on the law of the sea by Kolodkin, ${ }^{26}$ Gutsuliak, ${ }^{27}$ and Bobrova ${ }^{28}$ refers back to what the authors call the correct opinions of Molodtsov (who outright states that this decree does not touch upon the question of the legal status of the water areas so included) and Maleev (who adds that the sector lines did not constitute state boundaries), ${ }^{29}$ even though it still reprints the 1926 Decree. $^{30}$ The book of Kovalev, ${ }^{31}$ first published in 2003

\section{Id. at $168-69$.}

25. An overview of the period up to 1997 stated "that it is possible to conclude that a revision of the Arctic sector concept is occurring." Leonid Timchenko, The Russian Arctic Sectoral Concept: Past and Present, 50 ARCTIC 29, 33 (1997).

26. Professor Anatoly Kolodkin is judge at the International Tribunal for the Law of the Sea as well as the President of the Russian Associations of International Law and International Law of the Sea. See ANATOLY L. KolodKIN, VASILI N. GuTSULIAK, \& I. V. BOBROVA, MIROVOI OKEAN. MEZHDUNARODNO-PRAVOVOI REZHIM. OSNOVNYE PROBLEMY [THE WORLD OCEAN. INTERNATIONAL LEGAL REGIME. BASIC PROBLEMS] 2 (2007).

27. Professor Vasili Gutsuliak is affiliated with the Institute of State and Law of the Russian Academy of Sciences. Id.

28. Ms. Julya Bobrova is Chief-Specialist at the Ministry of Transport. She is also affiliated with the Department of International Sea and River Law of the Moscow State Academy for Water Transport. Id.

29. Id. at 261-62.

30. Id. at 261. This connection, often encountered in Russian writings, is rather awkward. It is illogical to refer to a decree, which is now accepted not to concern water expanses, when stating one's maritime policy in the Arctic. See Erik Franckx, Nature Protection in the Arctic: Recent Soviet Legislation, 41 INT'L \& COMP. L. Q. 366, 372 (1992). Others, however, have explained this reproduction of the 1926 Decree in the 1986 Soviet Notices to Mariners as appropriate and necessary in order to indicate that the territorial sea around these islands was Soviet and to control navigation of foreign warships. See Timchenko, supra note 25, at 33. But since all territorial claims had long since been settled in that area, the relevance of such argumentation in the past is to be doubted. See supra note 2 and accompanying text. This is true even if Wrangel is considered, as this island is not one in which the regime of innocent passage is of particular relevance (similar to other islands with overlapping territorial seas or straight baselines linking the island to the mainland).

A fortiori, such argumentation is no longer convincing at present because of the Russian acceptance of the right of innocent passage of warships in the territorial sea in the meantime. See generally Erik Franckx, Further Steps in the Clarification 
and translated into English a year later, takes a similar approach and adds:

[I]t follows, in our view, that one should proceed from the fact that the maritime expanses of the Northern Arctic Ocean are by their legal status subdivided into those same categories as the water expanses of the entire World Ocean, the legal regime of which is provided for in the 1982 [Convention]. ${ }^{32}$

It seems therefore safe to conclude that the latter idea is generally adhered to today in Russian doctrine. ${ }^{33}$

In 2001, when Robin Churchill considered whether claims to maritime zones in the Arctic were to be considered as law of the sea normality or polar peculiarity, he had no difficulty in concluding that maritime zones were a law of the sea normality. Even if Canada and Russia might be considered somewhat ambiguous in this regard, Churchill nevertheless concluded that "this ambiguity stems more from writers (and primarily from writers of the past) than their governments." ${ }^{134}$ The present findings seem to further confirm these

of the Soviet Position on the Innocent Passage of Foreign Warships Through Its Territorial Waters, 19 GA. J. INT'L \& COMP. L. 535 (1989); Erik Franckx, Innocent Passage of Warships: Recent Developments in U.S.-Soviet Relations, 14 MARINE POL'Y 484 (1990); FRANCKX, supra note 2, at 163-67; Erik Franckx, Onschuldige doorvaart van oorlogsschepen in de territoriale zee: herwaardeert de U.S.S.R. de inhoud van in onbruik vervallen teksten? [Innocent Passage of Warships in the Territorial Sea: Did the U.S.S.R. Revaluate the Content of Texts that had Fallen into Oblivion?], 18 BELGIAN REV. OF INT'L L. 272 (1984); Erik Franckx, The U.S.S.R. Position on the Issue of Innocent Passage of Warships Through Foreign Territorial Waters, 18 J. MAR. L. \& COM. 33 (1987). .

31. A. A. Kovalev, Contemporary Issues of the LAW of the Sea: MODERN RUSSIAN APPROACHES (W. E. Butler ed. \& trans., 2004). The author paraphrases the 1926 Decree and says the sector lines do not to constitute state boundaries. Id. at 178-79.

32. Id. at 182.

33. Of course, dissonant voices will always be heard-for example, A. V. Ovlashchenko \& I. F. Pokrovskii, Problemy pravovogo rezhima severnogo morskogo puti (k provedeniiu mezhdunarodnogo poliarnogo goda (2007-2008 G.G.) [Problems of the Legal Regime of the Northern Sea Route (at the Occasion of the International Polar Year 2007-2008)], 2 TRANSPORTNOE PRAVO 21-26 (2007)-but definitively seem to represent a minority opinion at present.

34. Robin R. Churchill, Claims to Maritime Zones in the Arctic: Law of the Sea Normality or Polar Peculiarity?, in THE LAW OF THE SEA AND POLAR 
406 California Western International Law Journal [Vol. 41

conclusions, namely that the 1982 Convention contains the generally applicable legal framework for the Arctic. It seems no longer warranted to differentiate the claims of Canada (namely the straightforward application of the general principles contained therein) and Russia (where no such clear-cut conclusion is reached but rather replaced by a much more qualified statement $)^{35}$ as to the effect of the 1982 Convention of the Arctic's ratifcation.

\section{Climate Change}

The findings of the Arctic Climate Impact Assessment are starting points with respect to climate change. These findings were the result of an international project between the Arctic Council and the International Arctic Science Committee, which were released in November $2004 .{ }^{36}$ Based on this detailed scientific analysis, a synthesis report put forward some practical conclusions by means of so-called key findings. ${ }^{37}$ Key Finding Number 6 of the synthesis report, entitled Reduced Sea Ice is Very Likely to Increase Marine Transport and Access to Resources ${ }^{38}$ is of particular relevance here. It notes a $5-10 \%$ estimated reduction in annual average sea-ice extent, most prominent in summer, as well as a $10-15 \%$ reduction in average thickness over the past few decades, with a $40 \%$ reduction in the central Arctic Ocean. ${ }^{39}$ Based on this data, longer seasons of less seaice cover of reduced thickness are expected, "implying improved ship accessibility around the margins of the Arctic Basin (although this will not be uniformly distributed)." ${ }^{40}$ This parenthetical caveat is further

MARITIME DELIMITATION AND JURISDICTION 105, 124 (Alexander G. Oude Elferink \& Donald R. Rothwell eds., 2001).

35. See Fabienne Quilleré-Majzoub, Glaces polaires et icebergs: Quid juris gentium?, 52 ANNUAIRE FRANÇAIS DE DROIT INTERNATIONAL 432, 436-37 (2006).

36. See generally ARCTIC ClimATE IMPACT ASSESSMENT (Carolyn Symon et al., eds., 2005), available at http://www.acia.uaf.edu/pages/scientific.html.

37. IMPACTS OF A WARMING ARCTIC: ARCTIC CLIMATE IMPACT ASSESSMENT (Susan J. Hassol ed., 2004), available at http://amap.no/acia (follow the "Impacts of a Warming Arctic" hyperlink, then follow hyperlinks for individual sections).

38. Id. at 82-85.

39. Id. at 82 .

40. Id. 
clarified in the report by distinguishing the Northern Sea Route, on the one hand, from the Northwest Passage on the other. ${ }^{41}$

As far as the Northern Sea Route is concerned, it is predicted that based on models derived from the above-made observations, the number of navigable days (days per year with less than $50 \%$ sea-ice concentration) will increase from 20-30 days in 2004 to 90-100 days in $2080 .{ }^{42}$ And, since icebreakers are able to manage waters with a sea-ice concentration of $75 \%$, this would in fact open up the Northern Sea Route to 150 days by $2080 . .^{43}$

The picture with respect to the Northwest Passage, however, is much more nuanced because the ice conditions in this part of the Arctic are less predictable. First of all, the Canadian Arctic is characterized by a high year-to-year variability despite the general decrease in sea-ice tendency since the late 1960 s. ${ }^{44}$ Moreover, because of the restricted nature of the waters inside the Canadian northern islands, the melting tendency could result in more icebergs moving into the routes normally used for navigation. ${ }^{45}$ With respect to the Northwest Passage, the synthesis concludes that "despite widespread retreat of sea ice around the Arctic Basin, it is clear that the unusual geography of the Canadian Arctic Archipelago creates exceptionally complex sea ice conditions and a high degree of variability for the decades ahead. $" 46$

More recent findings not only seem to sustain these predictions, but even predict an acceleration of the expected timescale of their realization. The exceptional summer melt of 2007 made scientists believe that summer ice might not even make it to $2050 .{ }^{47}$ Because of warmer ocean waters and higher spring temperatures over the Russian part of the Arctic during the spring of 2007 , for example, summers
41. Id.
42. Id. at 83 .
43. Id.
44. Id. at 84 .
45. Id. at 85 .
46. Id.
47. Richard A. Kerr, Is Battered Arctic Sea Ice Down for the Count?, SCIENCE, Oct. 5, 2007, at 33-34. 
without sea ice are now being predicted as soon as within the next forty years. ${ }^{48}$

This contrasts sharply with the possibility raised in 2004 that in place of an ice-free summer, changing climate patterns could instead usher in a new ice-age. ${ }^{49}$ But, this scenario seems so farfetched that the scientific community reacted by characterizing it as highly unlikely. ${ }^{50}$ Other phenomena may have been speeding up the present increase in melting, such as prevailing wind patterns during the $1990 \mathrm{~s}$, which might predict a slowdown in the melt rate in the future. ${ }^{51}$ Other scientists suggest a more cyclic temporary reprieve. ${ }^{52}$ Still, others emphasize that there is a lack of spatial uniformity in the melting pattern of, for instance, the Northwest Passage itself..$^{53}$ Nevertheless, the general trend towards "a seasonally ice-free Arctic Ocean as the system warms seems increasingly certain. The unresolved questions regard when this new arctic state will be realized, how rapid the

48. Daniel Cressey, Arctic Melt Opens Northwest Passage, NATURE, Sept. 20, 2007 , at 267.

49. See generally Peter Schwartz \& Doug RANDAll, AN ABRuPt Climate CHANGE SCENARIO AND ITS IMPLICATIONS FOR UNITED STATES NATIONAL SECURITY (2003), available at http://www.climate.org/PDF/clim_change_ scenario.pdf. The argument is that because of the melting ice, freshwater will change the structure of the usually salty and dense waters in the North and cause a thermohaline circulation collapse, preventing the warm Gulf stream from reaching the Arctic basin any longer. This scenario was picked up in the press afterwards. See, e.g., David Stipp, The Pentagon's Weather Nightmare. The Climate Could Change Radically, and Fast. That Would Be the Mother of All National Security Issues, FORTUNE, Feb. 4, 2004, at 100, available at http://money.cnn.com/magazines/fortune/fortune_archive/2004/02/09/360120/index. htm.

50. See, e.g., Wallace S. Broecker, Letter to the Editor, Future Global Warming Scenarios, SCIENCE, Apr. 16, 2004, at 388. In a reply, Schwartz and Randall stated that the purpose of their report was not to further climate science, but rather to imagine the unthinkable. Peter Schwartz \& Doug Randall, Future Global Warming Scenarios, Take 2, SCIENCE, Sept. 24, 2004, at 1911. Or, to use their own words: "We have created a climate change scenario that although not the most likely, is plausible." Id.

51. Richard A. Kerr, Scary Arctic Ice Loss? Blame the Wind, SCIENCE, Jan. 14, 2005, at 203.

52. Could Mother Nature Give the Warming Arctic a Reprieve?, SCIENCE, Jan. 5,2007 , at 36 .

53. Michael Bravo \& Gareth Rees, Cryo-Politics: Environmental Security and the Future of Arctic Navigation, 13 BROWN J. WORLD AFF. 205, 206 (2006). 
transition will be, and what will be the impacts of this new state on the Arctic and the rest of the globe." 54

Certainly, the dramatic rate at which melting has occurred lately has clear implications for navigation in the area. Satellite images captured during the exceptional summer of 2007 clearly indicate that the whole Northern Sea Route, including its natural choke point, Vil'kitskii Strait, ${ }^{55}$ was totally ice-free. ${ }^{56}$ Even more surprising, during the summer of 2007 , the Northwest Passage was totally ice-free as well. ${ }^{57}$

\section{Projected Consequences IN THe Legal SPHERE}

One can assume with reasonable certainty that the Arctic ice will diminish in extent, as well as in thickness, during the years to come. Even though the exact timeframe remains open to conjecture, the effects this will have on the legal regime of navigation in the Arctic seem considerable. At least five submissions can be made in this respect. ${ }^{58}$ First, as navigation becomes more intensive, the urge to conclude maritime boundary agreements will increase accordingly. As of now, almost all of these boundaries are awaiting final settlement. Secondly, present-day solutions to navigational problems will soon become totally insufficient. The so-called "agreement to disagree"59 concluded between Canada and the United States in the wake of the

54. Mark C. Serreze et al., Perspectives on the Arctic's Shrinking Sea-ice Cover, SCIENCE, Mar. 16, 2007, at 1533, 1536.

55. Vil'kitskii Strait is the most northerly located strait, and therefore normally the most difficult one, in terms of ice conditions, to be negotiated by vessels plying the Northern Sea Route. See generally Erik Franckx, Non-Soviet Shipping in the Northeast Passage, and the Legal Status of Proliv Vil'kitskogo, 24 POLAR REC. 269 (1988).

56. See Serreze et al., supra note 54 , at 1533 fig. 1.

57. See Kerr, supra note 47, at 34 fig. A plus.

58. These submissions were presented at the first seminar organized under the project "The Capability of International Governance Systems in the Arctic to Contribute to the Mitigation of Climate Change and Adjust to its Consequences" (Aug. 30-Sep. 3, 2006), organized by Arctic Centre of the University of Lapland, Rovaniemi, Finland. I presented a preliminary version of this Article in Pyhätunturi, Finland on September 1, 2006.

59. Ted L. McDorman, A Canadian Perspective on the Continued NonRatification of the Convention on the Law of the Sea by the United States, 43 CAN. Y.B. INT'L L. 393, 412 (2005). 


\section{CALIFornia Western InTERnational LaW Journal [Vol. 41}

Polar Sea crossing in 1985, for instance, will no longer be sufficient to regulate navigational issues between these two countries because this agreement is restricted to the crossings of U.S. Coast Guard vessels only ${ }^{60}$ Third, the validity of the straight baselines, especially the exact status of the waters so enclosed, will become topical once again. Fourth, whether the Northern Sea Route and Northwest Passage can be considered straits used for international navigation will become a very acute and extremely difficult issue to solve. Fifth, as the melting process continues to increase over time, coastal states' reliance on Art. 234 of the 1982 Convention ["Art. 234"] in order to restrict foreign navigation in the area will become less and less effective.

Will the 1982 Convention, believed to constitute the applicable legal regime, be able to take all these new concerns, triggered by climate warming in the Arctic, into consideration to allow an orderly development in the area? The next part will try to respond to this question.

\section{VULNERABILITY AND ADAPTIVE CAPACITY \\ OF THE 1982 CONVENTION}

\section{A. Vulnerability}

\section{Low-level Vulnerability}

The vulnerability of the 1982 Convention could be considered to stem from the attempt of its drafters to draw up one single legal instrument covering the whole law of the sea. This attempt is contrary to the previous approach taken by the International Law Commission when preparing the first United Nations Conference on the Law of the Sea in 1958. The 1958 conference resulted in the adoption of four nicely separated conventions, from which states could then pick and choose, supplemented by an optional dispute settlement protocol. ${ }^{61}$ The 1982 Convention, in contrast, intends to cover all activities in all oceans, including the Arctic. The inclusion of the Arctic Ocean can be

60. See Agreement on Arctic Cooperation and Exchange of Notes Concerning Transit of Northwest Passage, U.S.-Can., Jan. 11, 1988, 28 I.L.M. 141, 144-45 (entered into force Jan. 11, 1988).

61. Convention on the Territorial Sea and the Contiguous Zone, done Apr. 29, 1958, 504 U.N.T.S. 205 (entered into force Sept. 10, 1964). 
inferred by the 1982 Convention's inclusion of a special section in Part XII (Protection and Preservation of the Marine Environment), containing only one article with the same title as the section to which it belongs-"ice-covered areas." clearly underlines that it was meant to be applied specifically to the Arctic. ${ }^{63}$ It is easy to question how one short, single article could possibly deal with all the maritime issues of the Arctic, suggesting that this document is flawed as a governing legal framework in that area.

As already implied in Part I, while looking at things this way may be attractive to the layman, this approach can hardly be considered a sensible one from an international law point of view. ${ }^{64}$ As far as navigation is concerned, the 1982 Convention clearly starts from the premise - finally accepted by all Arctic states today, as argued in Part I-that normal rules of navigation apply in that area as well. This means that whether the issue concerns internal waters, baselines, bays, straits, territorial seas, exclusive economic zones or high seas-to name but the most salient ones-the relevant parts of the

62. 1982 Convention, supra note 3, at art. 234. Art. 234 reads:

Coastal States have the right to adopt and enforce non-discriminatory laws and regulations for the prevention, reduction and control of marine pollution from vessels in ice-covered areas within the limits of the exclusive economic zone, where particularly severe climatic conditions and the presence of ice covering such areas for most of the year create obstructions or exceptional hazards to navigation, and pollution of the marine environment could cause major harm to or irreversible disturbance of the ecological balance. Such laws and regulations shall have due regard to navigation and the protection and preservation of the marine environment based on the best available scientific evidence.

Id.

63. This article, which is sometimes referred to as "the Arctic article," was negotiated directly between the three countries most concerned at the time, namely Canada, the former Soviet Union, and the United States of America. See Article 234: Ice-Covered Areas, in UNITED NATIONS CONVENTION ON THE LAW OF THE SEA 1982: A COMMENTARY 392, 393 (Myron H. Nordquist, Shabtai Rosenne, Alexander Yankov \& Neal R. Grandy eds., 1991).

64. The comparison between the Northwest Passage and the use of the Mississippi River in order to come to grips with the applicable regime of navigation in the former, may seem attractive at first sight, Christopher M. Macneill, Gaining Command \& Control of the Northwest Passage: Strait Talk on Sovereignty, 34 TRANSP. L.J. 355, 365 (2007), but lacks, however, any plausible legal justification under contemporary international law. 


\section{CALIFORNIA Western InTERnational LAW JOURNAL [Vol. 41}

1982 Convention apply, as changed, where applicable, by the content of Art. 234. But even beyond the mere navigational concerns, it might suffice to illustrate the general applicability of this document by referring to the intense media coverage accompanying the Russian initiative during the summer of 2007 when one of its submarines planted a flag on the bottom of the ocean at the North Pole. Of course, a strategically sensitive area as the Arctic, such an action requires due attention. ${ }^{65}$ But despite what the titles of newspaper articles might have induced their readers to believe, this initiative did not set in motion a new, totally unregulated wave of national sovereignty claims to the Arctic proper resulting in bitter clashes with nobody out there to impose a negotiated solution. Indeed, the 1982 Convention not only created the legal justification for coastal states to establish sovereign rights over the seabed and subsoil beyond the 200 n.m. limit, but it also created a special body, the Commission on the Limits of the Continental Shelf, to help settle the outer limit of this area of state authority. ${ }^{66}$

The unitary character of this document is therefore, by itself, not to be considered as a prohibiting factor, preventing this document from securing an operational legal system in the Arctic. Instead, the fact that the dispute settlement provisions form an integral part of the package will prove to be a non-negligible advantage with respect to navigational matters, a point further developed in Part IV.B. The unitary character of the 1982 Convention can therefore be considered to fall in the category of low-level vulnerabilities.

\section{B. Medium-level Vulnerability}

Nevertheless, one must admit that this basic approach of the 1982 Convention, whereby the general rules on the law of the sea apply to the Arctic as well, with only one specific article solely devoted to the area in question, may imply that this legal document "cannot be seamlessly applied to the Arctic," as already mentioned. ${ }^{67}$ Indeed, there are a number of examples that have an impact on navigation, including the drawing of Arctic straight baselines by Canada and the

65. See generally James Stuhltrager, Global Climate Change and National Security, NAT. RESOURCES \& ENV'T, Winter 2008, at 36, 39-40.

66. 1982 Convention, supra note 3, at Annex II.

67. See Borgerson, supra note 9 , at 72 . 
former Soviet Union, which were either protested at the time of enactment on paper ${ }^{68}$ or thereafter in practice. ${ }^{69}$ Another example is the claim to historic waters in the Arctic, which in Canada concerns waters on the inside of those baselines, ${ }^{70}$ but in Russia also possibly concerns waters outside those baselines. Also, the reliance on the sector lines with respect to maritime delimitation (which Canada relies upon in its dispute with the United States, and Russia in its dispute with Norway), ${ }^{71}$ as well as the question whether the Northern Sea Route and Northwest Passage are, or could become, straits used for international navigation, can be mentioned in this respect. Finally, the issue of the correct application of Art. 234 (the only article in the 1982 Convention dealing exclusively with the Arctic, as already mentioned) can be raised in this respect, especially since parts of it can be considered as still being developed, ${ }^{72}$ such as its "due regard" provision through the International Maritime Organization as indicated below.

Most of these issues are highly contentious under present-day international law. With respect to the conformity of the baselines to international law, one finds arguments on both sides of the spectrum in legal writings relating to Canada $^{73}$ as well as Russia. ${ }^{74}$

68. The Canadian system of straight baselines triggered letters of protest by the United States and the European Community. J. ASHLEY ROACH \& ROBERT W. SMith, United States Response to EXCESsive MARITIME Claims 118, 121 (2d ed. 1996).

69. The Russian system north of the Eurasian continent was only challenged by the United States in 1992 by means of one of its submarines. Id. at 100 . Unlike the regular application of U.S. Freedom of the Sea program, this particular challenge apparently happened unintentionally. Erik Franckx, La collision entre deux sousmarins, un américain et un russe, dans la baie de Kola (mer de Barents), 1992 ESPACES ET RESSOURCES MARITIMES 33, 47 (1993) (Fr.).

70. See, for instance, the writings of Professor Donat Pharand, who still concludes that such a claim would not succeed on the historic title argument alone. DONAT PHARAND, CANADA'S ARCTIC WATERS IN INTERNATIONAL LAW 121-125 (1988); Pharand, supra note 21, at 5-13.

71. Victor Prescott \& Clive Schofield, The Maritime Political BOUNDARIES OF THE WORLD 525, 526 (2d ed. 2005).

72. Rob Huebert, Article 234 and Marine Pollution Jurisdiction in the Arctic, in THE LAW OF THE SEA AND POLAR MaRitime Delimitation and JuRISDiCTION, supra note 34 , at $249,267$.

73. Compare Tullio Scovazzi, The Baselines of the Territorial Sea: The Practice of Arctic States, in THE LAW OF THE SEA AND POlaR MARITIME 


\section{CALIFORNIA WESTERN INTERNATIONAL LAW JOURNAL [Vol. 41}

The issue of historic waters has been labeled as "one of the most controversial in the doctrine and practice relating to the law of the sea. This remains an open question both in the Arctic and in other areas of the world." 75 Especially in Canada, the view that the melting of the ice will diminish the strength of this historic internal waters claim has found proponents ${ }^{76}$ as well as opponents. ${ }^{77}$

So far, sector lines have been used only once in Arctic maritime delimitation, namely in the 1990 Agreement concluded between the former Soviet Union and the United States. ${ }^{78}$ This agreement, it should be remembered, has only entered provisionally into force because Russia has so far refused to ratify it. In the two other instances mentioned above, parties disagree about the relevance of sector lines in maritime boundary matters. Even though sector lines have been qualified as the most distinctive feature of Arctic maritime boundary delimitation, the final demise of this method has been

DELIMITATION AND JURISDICTION, supra note 34, at 69, 76-81, and PRESCOTT \& SCHOFIELD, supra note 71, at 520-21 (in conformity with international law), with Daniel Vignes, La conformité au droit de la mer des lignes de base droites tracées par le Canada au nord du 70ème parallèle nord, in INTERNATIONAL LAW AT A TIME OF PERPLEXITY: ESSAYS IN HONOUR OF SHABTAI ROSENNE 1005, 1019 (Yoram Dinstein ed., 1989) ("l'histoire n'est pas present au rendez-vous" [History is not present at the rendezvous]) (not in conformity with international law).

74. Compare R. Douglas Brubaker, The Legal Status of the Russian Baselines in the Arctic, 30 OCEAN DEVELOPMENT AND INTERNATIONAL LAW 191, 218 (1999) (in conformity with international law), with Stuart B. Kaye, Territorial Sea Baselines Along Ice-Covered Coasts: International Practice and Limits of the Law of the Sea, 35 OCEAN DEV. \& INT'L L. 75, 81-82 (2004), and W. MICHAEL REISMAN \& Gayl S. WESTERman, Straight Baselines in Maritime Boundary DELIMITATION 150-52 (1992) (not in conformity with international law).

75. Scovazzi, supra note 73 , at 84 .

76. See, e.g., Andrea Charron, The Northwest Passage: Is Canada's Sovereignty Floating Away?, 60 INT'L J. 831, 847-48 (2005); Rob Huebert, Climate Change and Canadian Sovereignty in the Northwest Passage, 2001 ISUMA 86, 89; Suzanne Lalonde, Increased Traffic Through Canadian Arctic Waters: Canada's State of Readiness, 38 REVUE JURIDIQUE THÉMIS 49, 124 (2004).

77. Franklyn Griffiths, New Illusions of a Northwest Passage, in InTERnational ENERGy POLICY, the ARCTIC AND tHE LAW OF tHE SEA 303, 303 (Myron H. Nordquist, John Norton Moore \& Alexander S. Skaridov eds., 2005); Franklyn Griffiths, The Shipping News: Canada's Arctic Sovereignty Not on Thinning Ice, 58 INT'L J. 257, 257 (2003); McRae, supra note 2, at 21-22.

78. See Elizabeth G. Verville, United States-Soviet Union (Report Number 16), in 1 INTERNATIONAL MARITIME BOUNDARIES, supra note 2, at 447. 
predicted, as Canada and Russia will find a solution with their neighbors for their remaining Arctic maritime boundary disputes. ${ }^{79}$

Whether the Northern Sea Route and the Northwest Passage should be considered straits used for international navigation is an issue still as hotly debated now as it was more than twenty years ago. ${ }^{80}$ How underwater navigation by submarines may impact this discussion is also hotly debated. ${ }^{81}$ It might be telling that in a recent article, an American scholar subtly referred to the statement-that the Northwest Passage had just been opened by two U.S. atomic submarines - by the chairman of the U.S. delegation to the second United Nations Conference on the Law of the Sea in $1960 .{ }^{82}$ Military cooperation between the American and Canadian armed forces only further complicates this issue. ${ }^{83}$

Finally, since Art. 234 has been negotiated directly between Canada, the former Soviet Union and the United States - countries with totally opposing interests in the area-it should not come as a surprise that problems of interpretation remain. In fact, this article has been described from the start as "probably the most ambiguous, if not controversial, clause in the entire treaty, $" 84$ or in a more metaphorical manner as "a witch's brew, a caldron of legal uncertainty which could be stirred in favour of either the coastal or shipping state." 85 The analysis by the Committee on Coastal State Jurisdiction Relating to Marine Pollution of the International Law Association, as reproduced

79. Alex G. Oude Elferink, Arctic Maritime Delimitations: The Preponderance of Similarities with Other Regions, in THE LAW OF THE SEA AND Polar MARITIME DELIMITATION AND JURISDICTION, supra note 34, at 179, 198.

80. Michael A. Becker, International Law of the Sea, 41 INT'L L. 671, 679-80 (2007) (describing new tensions in the Northwest Passage).

81. See, e.g., Donald M. McRae, Arctic Sovereignty: Loss by Dereliction?, in CANADA's ChANGING NORTH 427 (William C. Wonders ed., 2003) [hereinafter McRae, CHANGING NORTH]; McRae, supra note 2, at 15, 18-19, 21.

82. See Bernard H. Oxman, The Territorial Temptation: A Siren Song at Sea, 100 AM. J. INT'L L. 830, 849 n. 105 (2006).

83. See Michael Byers, Canadian Armed Forces Under United States Command, 58 INT'L J. 89, 95, 112-13 (2002).

84. Cynthia Lamson, Arctic Shipping, Marine Safety and Environmental Protection. 11 MARINE POL'Y 3, 4 (1987).

85. Cynthia Lamson \& David VanderZwaag Arctic Waters: Needs and Options for Canadian-American Cooperation, 18 OCEAN DEV. INT'L L. 49, 81 (1987). 


\section{CALIFORNIA WESTERN INTERNATIONAL LAW JOURNAL [Vol. 41}

in its final report of 2000 , gives a good overview of these many difficulties of interpretation. ${ }^{86}$ Despite the legal framework available, are we still lost at sea if the only article specifically applicable to the Arctic does not really provide clear and firm guidance?

It is not the goal of this Article to try to give concrete answers to the above-mentioned outstanding Arctic issues in the framework of the 1982 Convention, based on a detailed legal analysis. Moreover, space limitations would not allow for such an analysis. This Article's purpose is simply to illustrate that the 1982 Convention certainly has its vulnerabilities, and that the lack of specificity may be considered one of them. Certainly, if the law is not clear and is open to broadly diverging interpretations, states will naturally try to construe the law in a way most advantageous to their own situation. With respect to the legal nature of the Northwest Passage, it has, for instance, even been doubted whether the 1982 Convention provides the definitive answer. ${ }^{87}$ Since these national claims appear to be developed praeter or secundum legem, they are qualified as medium-level vulnerabilities for the purpose of this study.

\section{High-level Vulnerability}

Even more than the lack of specificity, the real vulnerability of the 1982 Convention is believed to stem from the attempts of certain coastal states to unilaterally try to change the content of certain convention provisions, which was set up as a package deal from which no derogations are allowed. ${ }^{88}$ This trend of so-called creeping jurisdiction-which at times has put pressure on the 1982 Convention in other areas ${ }^{89}$ - certainly existed in the Arctic in the past, ${ }^{90}$ and still

86. ERIK FranckX, Vessel-Source Pollution and CoAstal State JURISDICTION: THE WORK OF THE ILA JURISDICTION RELATING TO MARINE POLLUTION (1991-2000), at 100-05 (2001).

87. See generally McRae, CHANGING NORTH, supra note 81.

88. This document, it must be remembered, does not allow for reservations or exceptions, unless explicitly allowed by it. See 1982 Convention, supra note 3, at art. 309.

89. For more about the pressure placed on the 200 -mile limit, see, for instance, my recent writings including: Erik Franckx, The 200-mile Limit: Between Creeping Jurisdiction and Creeping Common Heritage?, 48 GER. Y.B. INT'L L. 117 (2005); Erik Franckx, 200 morskikh mil' $i$ polzuchaia iurisdiktsiia [200 n.m. Limit and Creeping Jurisdiction], 25 Mezhdunarodnoe PRAvo [Mez. Pra.] 206 (2006) 
has a tendency to resurface there. Indeed, in some instances the normal reading of the law does appear to be clear. Nevertheless, states develop arguments with respect to such clear provisions, no longer secundum or praeter legem, but rather contra legem. One such example will be given for each of the two gate holders of Arctic shipping, namely Canada and Russia.

\section{Canada}

As far as Canada is concerned, the application of Article 8, Section 2 of the 1982 Convention ("Art. 8 (2)") springs to mind. This Article reads as follows: "[W]here the establishment of a straight baseline in accordance with the method set forth in article 7 [(straight baselines)] has the effect of enclosing as internal waters areas which had not previously been considered as such, a right of innocent passage as provided in this Convention shall exist in those waters." 91 It seems undeniable that before drawing straight baselines in 1985, Canada did not consider the waters on the inside of these baselines as internal waters. The mere fact that the governmental reaction to the Manhattan crisis between 1969 and 1970 consisted, inter alia, of enlarging the territorial sea to $12 \mathrm{n} . \mathrm{m}$. (in order to be able to better control shipping at the east and west entrances of the Northwest Passage) appears to be sufficient proof of the matter. ${ }^{92}$

One detailed argument suggests that as long as Canada was not a party to the 1982 Convention, Art. 8 (2) did not apply to it. ${ }^{93}$ Yet, it appeared logical to conclude that if Canada became a party to this legal instrument, Art. 8 (2) would fully apply. As mentioned above, the latter happened in $2003 .{ }^{94}$ But, Pharand now comes to the

(Russ.); Erik Franckx, 200 n.m. Limit and Creeping Jurisdiction, 2005 EZHEGODNIK MORSKOGO PRAVA 63 (2006) (Russ.); Erik Franckx. 200 n.m. Limit and Creeping Jurisdiction. MEZ. PRA. 235 (2006) (Russ.); Erik Franckx, The 200-mile Limit: Between Creeping Jurisdiction and Creeping Common Heritage? Some Law of the Sea Considerations from Professor Louis Sohn's Former LL.M. Student, 39 GEo. WASH. INT'L L. REV. 467 (2007).

90. See FRANCKX, supra note 2, at 298.

91. 1982 Convention, supra note 3 , at art. $8, \S 2$.

92. See, e.g., FRANCKX, supra note 2, at 101-07.

93. See PHARAND, supra note 70, at 113-25.

94. See supra text accompanying note 13 . 


\section{CALIFORNIA WESTERN INTERNATIONAL LAW JOURNAL [Vol. 41}

conclusion that these baselines were drawn nearly twenty years before Canada joined the 1982 Convention. ${ }^{95}$ At that time, Canada was not bound by Art. 8 (2) or the corresponding rule of the 1958 Convention (to which Canada was not a party), nor a corresponding rule of customary law. ${ }^{96}$ The argument is that the rule contained in Art. 8 (2) is not automatically compulsory for all parties to the 1982 Convention, but only for those who established straight baselines after they became a party to the 1982 Convention. ${ }^{97}$ A similar line of reasoning can also be found in the writings of other Canadian authors. ${ }^{98}$ These authors sometimes stress the fact that the explicit wording "in accordance with . . . article 7," to be found in Art. 8 (2), further exonerates Canada in a more formal sense because it did not establish its system of straight baselines in 1985 on the legal basis of article 7 ("Art. 7"), since it was not yet a party to the 1982 Convention. ${ }^{99}$

The substantive argument seems rather strange, as it would imply, for instance, that if a country like Peru were to become a party to the 1982 Convention tomorrow, it could claim that article 3, establishing a maximum territorial sea width of 12 n.m., would not be applicable to it. At the time Peru claimed a 200 n.m. zone, it was neither bound by this article, nor by the 1958 Convention (indirectly limiting the territorial sea to a maximum of 12 n.m.), nor by customary international law (the exact content of which was at that time very much contested). This kind of intertemporal application of the 1982 Convention stands at odds with the package deal approach, which forms its backbone. Or, as more generally stated by one author: "This [Canadian] approach is unconvincing; otherwise, the entire range of excessive claims predating the 1982 Convention similarly would be permissible-creating a global crazy quilt of conflicting maritime claims and defeating the purpose of the [1982] Convention

95. Pharand, supra note 21 , at 43.

96. See Pharand, supra note 21, at 42-44.

97. See McRae, supra note 2, at 13-14.

98. See Michael Byers, Internationales Recht und Internationale Politik in der Nordwestpassage: Konsequenzen des Klimawandels, 67 ZEITSCHRIFT FÜR AUSLÄNDISCHES ÖFFENTLICHES RECHT UND VÖLKERRECHT [ZAÖRV] 145, 152 (2007) (Ger.).

99. Lalonde, supra note 76, at 78-79. 
as "one gigantic package deal." 100 Also, the more formalistic argument, based on the explicit reference to Art. 7, is not really convincing because Art. 8 (2) simply refers to "the method" set forth in Art. 7, not that particular article of that particular convention.

\section{Russia}

With respect to Russia, a non-negligible issue concerns the exact field of application of the Russian regulations concerning the Northern Sea Route. ${ }^{101}$ By itself, the concept of the Northern Sea Route is not free from ambiguity when compared to the related notion of the Northeast Passage. Authors very often find it essential to stress the importance of the difference, but when trying to explain the distinguishing elements the picture becomes rather hazy. ${ }^{102}$ As it presently stands, the Northern Sea Route forms part, be it a basic part, of the Northeast Passage, which is the larger entity. ${ }^{103}$

This primarily has to do with the horizontal extent of both seaways. The Northern Sea Route is said to start in the Arctic in the west from the western entrances of Novaia Zemlia, ${ }^{104}$ whereas the

100. James Kraska, The Law of the Sea Convention and the Northwest Passage, 22 INT'L J. MARINE \& COASTAL L. 257, 272 (2007).

101. MARINE \& ENV'T LAW INST., GOVERNANCE OF ARCTIC MARINE SHIPPING 63 (2008), available at http://archive.arcticportal.org/391/01/AMSA-ShippingGovernance-Final-Report---Revised-November-2008.pdf.

102. See, e.g., KOROLEVA ET AL. supra note 22, at 48-49, 98-99; Timchenko, supra note 25, at 31; Leonid Timchenko, The Northern Sea Route: Russian Management and Jurisdiction over Navigation in Arctic Seas, in THE LAW OF THE SEA AND POLAR MARITIME DELIMITATION AND JURISDICTION, supra note 34, at 269 , 269-71.

103. See Alexander G. Granberg, Vladimir V. Mikhailichenko, Vsevolod I. Peresypkin \& Alexander P. Ushakov, Istoriia Severnogo morskogo puti [History of the Northern Sea Route], in PROBLEMY SEVERNOGO MORSKOGO PUTI, supra note 2, at 9,9-10. The Northeast Passage can therefore be described as covering all maritime areas north of the Eurasian continent and limited by the maritime boundary with Norway to the West, the maritime boundary with the US to the East, and the North Pole to the North.

104. 1990 Regulations for Navigation on the Seaways of the Northern Sea Route, approved by USSR Minister of Merchant Marine, Sept. 14, 1990, available at

http://www.morflot.ru/about/sevmorput/en/ (follow the "Rules of Navigation.doc" hyperlink for English translation). 
Northeast Passage also includes the Barents Sea. However, recent statements made by the Director of the Northern Sea Route Administration, A. Gorshkovsky-declaring that the 1996 Guide to Navigation (applicable to the Northern Sea Route) also applies to the ice-covered parts of the Barents Sea ${ }^{105}$-and, inter alia, the editors of a recent authoritative book on the Northern Sea Route-stating that the Route's "functional boundaries" extend to the ice-covered parts of the southeastern Barents Sea ${ }^{106}$ - seem to blur the only remaining clear distinction between the Northeast Passage and the Northern Sea Route.

When one looks at the difference in vertical application of the Northeast Passage and the Northern Sea Route, one runs into even more difficulties. Because the present-day Russian legislation applicable to the Northern Sea Route is based on the extended competence granted to coastal states in ice-covered areas in accordance with Art. 234, it normally implies that the application of this particular legal framework should be restricted to the 200 n.m. exclusive economic zone. Everything beyond that falls under the concept of the Northeast Passage. However, when the 1990 Regulations were established, it was argued that the Northern Sea Route varies great distances in latitude depending on the ice conditions-sometimes even passing through portions of the high seas. ${ }^{107}$ Today, this position seems to be the prevailing attitude in Russian doctrine, reflected not only in the specialized literature on the

105. ANATOLY GORSHKOVSKY, RULES TO BE FOLLOWED ON THE NORTHERN SEA ROUTE (DEliVERABle No. D.6.1 IN THE FRAMEWORK OF THE ARCTIC OPERATIONAL PlatForM PROJECT; PROCEEDINGS OF A WORKSHOP HELD ON 25 MARCH 2003, HELSINKI, FINLAND) 27-28 (2003). The 1996 Guide to Navigation includes the full text of the 1990 Regulations, as well as the 1996 Regulations and Requirements, constituting the present legal regime applicable to the Northern Sea Route. See MARINE \& ENV'T LAW INST., supra note 101, at 62-67.

106. See Granberg et al., supra note 103, at 10; Alexander G. Granberg, Vladimir V. Mikhailichenko, Vsevolod I. Peresypkin \& Alexander P. Ushakov, Okontseptsii razvitiia Severnogo morskogo puti $[$ On the Concept of the Development of the Northern Sea Route], in PROBLEMY SEVERNOGO MORSKOGO PUTI, supra note 2, at 502, 503.

107. Anatoliy L. Kolodkin \& M.E. Volosov, The Legal Regime of the Soviet Arctic: Major Issues, 14 MARINE POL'Y 158, 164 (1990). 
law of the sea, ${ }^{108}$ but also in general works on international law. ${ }^{109}$ The Russian practice of experimenting with variants to the standard itineraries normally followed by ships plying the Northern Sea Route ${ }^{110}$ seems to be particularly relevant in this respect. ${ }^{11}$

All of this seems to boil down to the position that in the Arctic, the Northern Sea Route equates to the Northeast Passage-certainly east of the western entrances to Novaia Zemlia as already suggested in certain western publications, ${ }^{112}$ and maybe even including large parts of the Barents Sea. How all this is to be reconciled with the straightforward notions of Art. 234, using terminology such as "within the limits of the exclusive economic zone" and "the presence of ice covering such areas for most of the year," 113 is extremely hard to understand.

Since such examples seem to contradict the basic legal framework applicable in the Arctic, they have been qualified as high-level vulnerabilities for the purpose of the present paper.

108. V. N. GUTSULIAK, MEZHDUNARODNOE MORSKOE PRAVO (PUBLICHNOE I Chastnoe) [International Law of the Sea (Public AND Private)] 96-98 (2006); KOLODKIN ET AL., supra note 26, at 264.

109. IGOR I. LUKASHUK, MEZHDUNARODNOE PRAVO: OSOBENNAIA CHAST' [INTERNATIONAL LAW: SPECIAL PART] (2005).

110. This practice involves either circumnavigating some or all of the Russian Arctic islands to the north-called transit voyages-or crossing the North Pole area-called trans-Arctic voyages.

111. S. V. Brestkin et al., Prirodnye usloviia na trassakh Severnogo morskogo puti [Natural Conditions on the Itineraries of the Northern Sea Route], in PROBLEMY SEVERNOGO MORSKOGO PUTI, supra note 2, at 106, 127-33.

112. See Brubaker, supra note 74, at 208; R. Douglas BrubaKeR, THE RUSSIAN ARCTIC STRAITS 6-14 (2005) [hereinafter Brubaker, ARCTIC STRAITS]; PETER ØREBECH \& R. DOUglas BRUBAKER, LEGAL STATUS OF THE NSR: STATE OF THE ART REPORT (DELIVERABLE NO. D2.1.1 IN THE FRAMEWORK OF THE ARCTIC OPERATIONAL PLATFORM PROJECT) 6 (2006). Each of the aforementioned sources depict the Northern Sea Route by means of a line running from the northern tip of Novaia Zemlia, up to the North Pole, and then back to the Bering Strait.

113. 1982 Convention, supra note 2 , at art. 234. Warming ocean temperatures ( 3 degrees Celsius since 1980 in winter) have been held responsible for a decrease in winter-ice in the Barents Sea, which will lead to even less summer ice in the future. Rising Surface Temperatures Drive Back Winter Ice in Barents Sea, SCIENCE DAILY, Sept. 20, 2007, http://www.sciencedaily.com/releases/2007/09/070917172937.htm. Taking into account the prevailing ocean currents in the southeastern part of the Barents Sea, the timing of this proposed extension of the legal regime of the Northern Sea Route is unfortunate. 


\section{B. Adaptive Capacity}

In view of all these vulnerabilities of the 1982 Convention, the next question I address is whether this document, and the atypical regime it represents, possesses sufficient adaptive capacity to alleviate these new strains global warming poses upon the Arctic navigation regime.

Indeed, the 1982 Convention is different from many other international agreements in that it neither bestows a specifically established body nor the conference of the parties with the specific task of developing the instrument itself. Even though the conference of the parties is mentioned in article 319 , this body has merely been attributed with administrative powers relating to appointments or financial matters. Whether this body also has the power to review the functioning of the 1982 Convention itself is far from clear since widely diverging opinions exist among states in this respect. ${ }^{114}$ Furthermore, no procedure to further develop the instrument through protocols or annexes has been included in this document; only an amendment procedure (articles 312-16) is provided, which appears rather difficult to apply in practice. ${ }^{115}$ Despite these specificities, the overall adaptive capacity of this document has not been considered inferior to other dynamic or living instruments. A substantial mix of additional legally binding agreements - whether universal or regional-and soft law clearly make the 1982 Convention a non selfcontained legal regime. ${ }^{116}$ The general adaptive capacity of the latter regime finds no exception in the Arctic, as will be argued next.

114. See, e.g., Alexander G. Oude Elferink, Reviewing the Implementation of the LOS Convention: The Role of the United Nations General Assembly and the Meeting of States Parties, in 44 OCEANS MANAGEMENT IN THE 21ST CENTURY: INSTITUTIONAL FRAMEWORKS AND RESPONSES 295 (Alexander G. Oude Elferink \& Donald. R. Rothwell eds., 2004).

115. David Freestone \& Alexander G. Oude Elferink, Flexibility and Innovation in the Law of the Sea: Will the LOS Convention Amendment Procedures Ever be Used?, in STABILITY AND CHANGE IN THE LAW OF THE SEA: THE ROLE OF THE LOS CONVENTION 169, 173-83 (Alexander G. Oude Elferink ed., 2005).

116. Alan Boyle, Further Developments of the Law of the Sea Convention: Mechanisms for Change, 54 INT'L \& COMP. L.Q. 563, 584 (2005) [hereinafter Boyle, Mechanisms]; Alan Boyle, Further Development of the 1982 Convention on the Law of the Sea: Mechanisms for Change, in THE LAW OF THE SEA: PROGRESS 
It is believed that this document is rather well equipped to deal with the different possible scenarios, especially as far as navigation in the Arctic is concerned. First of all, one may not forget that Art. 234 is quite exceptional in the overall framework of the 1982 Convention. Art. 234 is the only place where national rules concerning vesselsource pollution need not conform to generally accepted international rules and standards. ${ }^{117}$ Art. 234 implies that if Arctic shipping picks up, the coastal states retaining control over the Northern Sea Route and the Northwest Passage will have ample room to protect their maritime zones. At the same time, however, it must be noted that coastal states' extensive powers are not totally discretionary, for Art. 234 contains the obligation that they give "due regard to navigation,"118 while establishing their laws and regulations concerning shipping.

The flexibility included in this notion enhances the adaptive capacity of the article. The fact that the parties involved will very often have a different interpretation of this vague notion is not to be considered an added vulnerability; Art. 234 remains subject to the system of compulsory dispute settlement, as stressed by Conclusion No. 14 of the Committee on Coastal State Jurisdiction Relating to Marine Pollution of the International Law Association. ${ }^{119}$ If shipping increases in the future, a neutral third party appointed in accordance with Part XV of the 1982 Convention (Settlement of Disputes) will always be able to give concrete content to this vague notion, balancing the interests of both the coastal state and the flag state. Or, as stated by one author:

As these duties of due regard are mutually applicable, the potential for them to regulate a dispute between users is slight. It is only when due regard obligations can be subjected to third-party procedures that the possibility exists for these duties to have a

AND PRosPECTS 40, 52-55 (David Freestone, Richard Barnes \& David M. Ong eds., 2006) [hereinafter Boyle, Further Development].

117. Barbara KWIATKOWSKa, THE 200 Mile EXClusive ECONOMIC ZONE IN THE NEW LAW OF THE SEA 176 (1989).

118. Id.

119. See FRANCKX, supra note 86, at 104. 


\section{4} CALIFORNIA WESTERn InTERnational LAW JOURNAL [Vol. 41

meaningful application that would take into account the differing circumstances. ${ }^{120}$

The ultimate purpose of Part XV is to balance the coastal state powers granted in Parts V (Exclusive Economic Zone) and XII (Protection and Preservation of the Marine Environment) to the advantage of the freedom of navigation. ${ }^{121}$ While Art. 234 leaves large discretion to the coastal state when regulating navigation in ice-infested waters, it clearly does not give the coastal state carte blanche; thus, if shipping were to increase in the future, it allows for the orderly development of the law. The guidelines in the framework of the International Maritime Organization for ships operating in icecovered waters, ${ }^{122}$ as well as the additional work by the International Association of Classification Societies in this respect, ${ }^{123}$ may already be considered a multilateral effort trying to give concrete content to this notion of due regard in the framework of Art. $234 .{ }^{124}$ Part XV of the 1982 Convention was primarily accepted by its founding fathers in order to "maintain the integrity of the Convention's compromise package." 125 Art. 234 forms a case in point as far as the practical implementation of this general policy is concerned. Moreover, the interpretation given to such terms is not ex tunc, but ex nunc; so, if shipping increases as a result of climate change, "due regard" will have to be interpreted in a context of increased navigation and not in that of the sporadic journeys as they existed in 1982 when this

120. Natalie Klein, Dispute Settlement IN the UN CONVENTION ON THE LAW OF THE SEA 139 (2005).

121. Alan E. Boyle, Dispute Settlement and the Law of the Sea Convention: Problems of Fragmentation and Jurisdiction, 46 INT'L \& COMP. L.Q. 37, 42 (1997).

122. Int'l Mar. Org. [IMO], Guidelines for Ships Operating in Arctic IceCovered Waters, MSC/Circ. 1056 (Dec. 23, 2002), available at http://www.gc.noaa.gov/documents/gcil_1056-MEPC-Circ399.pdf.

123. Øystein Jensen, Arctic Shipping Guidelines: Towards a Legal Regime for Navigation Safety and Environmental Protection?, 44 POLAR REC. 107, 110 (2008).

124. See Huebert, supra note 72 , at 263-66. Being a non-legal document, this should, however, only be considered a first effort. What about: This document should, however, only be considered a first effort because it is a non-legal document

125. John E. Noyes, Compulsory Third-Party Adjudication and the 1982 United Nations Convention on the Law of the Sea, 4 CONN. J. INT'L L. 675, 682 (1989). 
convention was concluded. Such terms, in other words, allow an evolutionary interpretation. ${ }^{126}$

The only article of the 1982 Convention exclusively dealing with the Arctic seems especially well suited to take into account climate change not only in a medium, but also in a long-term perspective. As further warming, in a first phase, will most probably make ice-breaker assisted navigation more plausible, the situation just described will apply. But if in the long run not only ice-free summers, but maybe even ice-free winters were to become a reality, the adaptive capacity of Art. 234 appears to be extremely well suited to take into consideration such new developments as well. It must be remembered that the notion of Arctic waters is nowhere used in the article; it only mentions "ice-covered areas," which has been defined in the article itself, as already mentioned above, as "ice covering such areas for most of the year." 27 So, even were ice to disappear completely in the Arctic, this article would be well adapted to the different steps in the climatic process leading up to that eventuality. The article would simply stop being operative any longer somewhere along that process, implying that no specific coastal state powers are needed anymore and these Arctic waters would become totally governed by the normal rules of navigation to be found elsewhere in the 1982 Convention.

Since there appears to be no good reason why Art. 8 (2) should be excluded from the compulsory dispute settlement part of the 1982 Convention, it seems that those issues that have been characterized as high-level vulnerabilities are covered by Part XV. Therefore, these high-level vulnerabilities should not normally disturb the navigational regime if and when that navigational regime becomes fully operational. Instead, all these issues would be solved by making use of the procedures explicitly provided by the 1982 Convention for those purposes.

Part III (Straits used for International Navigation) should not be excluded from the system of compulsory dispute settlement either, especially since it squarely relates to the freedom of navigation. The same, in principle, holds true with respect to the issue of straight baselines. However, if straight baselines were tangled up with other issues, such as historic waters or maritime boundary delimitation, it

126. See Boyle, Further Development, supra note 116, at 44-49.

127. See supra note 62 and accompanying text. 


\section{6}

CALIFORNIA WESTERn INTERNATIONAL LAW Journal [Vol. 41

would be for the body competent under Article 287 to decide how to characterize the dispute in question. ${ }^{128}$ Indeed, Canada and Russia have listed historic bays and titles, as well as maritime boundary delimitations, as optional exceptions under Article 298. ${ }^{129}$ The United States, if it ever becomes a party to the 1982 Convention, will very likely act accordingly. ${ }^{130}$ Consequently, these latter issues will remain without a solution if the parties cannot find common ground in a negotiated manner; however, the vulnerability of these issues in the Arctic can hardly be considered as specific to that area.

Moreover, the qualification of the 1982 Convention as the Constitution for the Oceans, as previously mentioned, should not give the impression that further developments are especially hard or even impossible to reach. Indeed, constitutions come in different forms and while some of them have proven difficult to amend, others have been changed on a rather regular basis. The 1982 Convention clearly falls into the latter category, for it has already been "implemented" twice. ${ }^{131}$ Nothing prevents it from being "implemented" a third time, if this should prove necessary. And though some have suggested this should happen with respect to the Arctic in general, ${ }^{132} \mathrm{I}$ am not convinced that such development should be envisaged at present, and certainly not in order to be able to cope with future navigational issues. Of course, the conclusion of regional agreements, which the 1982 Convention does not preclude, is always possible. Scholars

128. See KLEIN, supra note 120 , at $272-73$.

129. See supra note 14 and accompanying text.

130. See, e.g., JoE BIDEN, Convention on the LAW of THE SEA, S. ExEC. DoC. No. 110-9 (1 st Sess. 2007), available at http://www.gpo.gov/fdsys/pkg/CRPT110erpt9/pdf/CRPT-110erpt9.pdf.

131. Agreement Relating to the Implementation of Part XI of the United Nations Convention on the Law of the Sea of 10 December 1982, opened for signature July 28, 1994, 1836 U.N.T.S. 3 (entered into force July 28, 1996), available at http://www.un.org/Depts/los/convention_agreements/texts/unclos/ closindxAgree.htm; Agreement for the Implementation of the Provisions of the United Nations Convention on the Law of the Sea of 10 December 1982 Relating to the Conservation and Management of Straddling Fish Stocks and Highly Migratory Fish Stocks, adopted Aug. 4, 1995, 34 I.L.M. 1542 (entered into force Dec. 11, 2001).

132. Barry Hart Dubner, On the Basis for Creation of a New Method of Defining International Jurisdiction in the Arctic Ocean, 13 Mo. ENVTL. L. \& POL'Y REV. 1, 18 (2005). 
contend that the regional agreements constitute "a significant source of further development of the law of the sea." 133 Once again, the Arctic forms no exception, as a certain interplay with the 1982 Convention has already been noted. ${ }^{134}$ These regional agreements can encompass either the involvement of competent international organizations, in casu the International Maritime Organization, or

regional navigational arrangements, as suggested by others, ${ }^{135}$ so long as these regional agreements comply with Article 311 of the 1982 Convention. As already mentioned, the 2002 Guidelines may provide a good example of the former.

\section{CONCLUSIONS}

Starting out from the predicted climate change, indicating that ice cover in the Arctic Ocean will continue to diminish during the years to come, this Article highlights some navigational concerns that will most certainly require increased international attention in the future. Even though the exact timing may remain open to conjecture at present, the fact that these issues will arrive on the international agenda seems generally accepted.

This Article also highlights the vulnerabilities of the international legal regime based on the 1982 Convention, which seems to be generally accepted by all major players in the Arctic today as containing the basic legal rules governing the area. For mere didactical purposes, a distinction was made between low, medium and high-level vulnerabilities. This Article reaches the conclusion that the listed high-level vulnerabilities, as well as a good number of mediumlevel vulnerabilities, can be solved in a satisfactory manner on the basis of the 1982 Convention itself. Other medium-level vulnerabilities, it must be admitted, cannot; but this difficulty is not specific to the Arctic region. It is nevertheless presumed that if navigation really starts to pick up in the Arctic, the coastal states will feel the urge to further their efforts at arriving at a negotiated solution with more vigor, whether it concerns maritime boundary questions or more strict navigational issues. In a region as sensitive as the Arctic,

133. See Boyle, Mechanisms, supra note 116, at 575.

134. See Olav Schram Stokke, A Legal Regime for the Arctic? Interplay with the Law of the Sea Convention, 31 MARINE POL'Y 402 (2007).

135. See BRUBAKER, ARCTIC STRAITS, supra note 112, at 6-14. 
for instance, the grounding of a vessel in a contested zone might easily trigger similar heated reactions as between Greece and Turkey during the mid-1990s, even in the absence of territorial disputes over islands. ${ }^{136}$ With respect to navigational issues as such, the transformation of the 2002 Guidelines into a legally binding document should be envisaged. ${ }^{137}$

The submission is therefore made that the 1982 Convention appears to have enough adaptive capacity to develop increased navigation into the Arctic in an orderly manner once it occurs. Now that all directly interested players finally accept the 1982 Convention as the basic legal regime governing the Arctic, it would be counterproductive to create a totally novel legal instrument. It is hoped the obligation for state parties to settle most future disputes in this area in accordance with the Part XV of the 1982 Convention will break the vicious circle of unilateral action-reaction, which has been so typical of the development of the Arctic navigational matters so far. It is therefore hoped that the United States will become a party to this document before the Arctic really opens up. The possibility of increased navigation in the Arctic adds one more good reason to the already long list of reasons why the U.S. Senate should give its advice and consent to this document.

136. See Martin Pratt \& Clive Schofield, The Imia/Kardak Rocks Dispute in the Aegean Sea, 4 BOUNDARY \& SEC. BULL. 62 (1996); Constantin Economidès, Les ilots d'Imia dans la Mer Egée: un différend créé par la force [Imia Islets in the Aegean: A Dispute Created by Force], 101 RevUE GenERALE DE DRoIT INTERNATIONAL PUBLIC 323 (1997) (Fr.).

137. See Jensen, supra note 123 , at 113. 


\section{POST-SCRIPTUM}

Since the spring of 2008, a number of developments have occurred that are worth pinpointing in a succinct manner with appropriate references ${ }^{138}$ in order to allow the reader to update the above-made legal analysis. Some of these developments were covered in the French version of this Article that appeared in 2009, which primarily concerned two documents-a joint document emanating from the five Arctic rim countries and one policy paper prepared by the Commission of the European Union. ${ }^{139}$ The so-called Ilulissat Declaration of the five Arctic countries is important because it emphasizes that, in the opinion of Canada, Denmark, Norway, Russia and the United States, the 1982 Convention provides a solid and, at the same time, sufficient foundation to regulate the Arctic in a responsible manner. ${ }^{140}$ The communication of the Commission of the European Union of November 20, 2008, even though a little bit more nuanced, nevertheless starts from the same premise: the 1982 Convention should be the basis of any further legal developments. ${ }^{141}$

In addition to the developments mentioned in the 2009 French version of this Article, there are several other developments to

138. All of these references are to English documents, except as otherwise indicated.

139. Erik Franckx, L'Arctique. Du changement climatique au changement juridique?, in L'ÉVOLUTION ET L'ÉTAT ACTUEL DU DROIT INTERNATIONAL DE LA MER. MÉlANGES DE DROIT DE LA MER OFFERTS À DANIEL VIGNES 299, 302, 303 (Raefael Casado Raigon \& Guiseppe Cataldi, eds., 2009).

140. This declaration was adopted at Ilulissat, Greenland by the Ministers of Foreign Affairs of the above-mentioned countries on May 28, 2008. Ilulissat Declaration, adopted May 28, 2008, available at http://arcticcouncil.org/filearchive/Ilulissat-declaration.pdf.

141. Communication From the Commission to the European Parliament and the Council: The European Union and the Arctic Region, at 9-10, COM (2008) 763 final (Nov. 20, 2008), available at http://eur-lex.europa.eu/LexUriServ /LexUriServ.do?uri=COM:2008:0763:FIN:en:PDF. That this document is nevertheless more nuanced is demonstrated by the following policy objective: "The full implementation of already existing obligations, rather than proposing new legal instruments should be advocated. This however should not preclude work on further developing some of the frameworks, adapting them to new conditions or Arctic specificities." Id. at 10. 
consider. First, on January 20, 2011, the European Parliament adopted a non-legislative resolution, entitled "A Sustainable EU Policy for the High North," in response to the aforementioned communication of the Commission. ${ }^{142}$

Secondly, all Arctic rim countries, with the exception of Norway, which already enacted its Arctic policy on December 1, 2006, ${ }^{143}$ have only issued such Arctic policy statements since the spring of 2008 (Denmark (May 2008), ${ }^{144}$ Canada (July 26, 2008) ${ }^{145}$ the Russian Federation (September 18, 2008) ${ }^{146}$ and the United States (January 9, 2009)). ${ }^{147}$ And once again, a recent study analyzing and comparing these five national Arctic policies starts from the assumption that "the

142. European Parliament Resolution of 20 January 2011 on a Sustainable EU Policy for the High North (Jan. 20, 2011), http://www.europarl.europa.eu/ sides/getDoc.do?type $=$ TA\&language $=E N \&$ reference=P7-TA-2011-0024. The 1982 Convention is the first document to which this resolution has regard to in the preamble. $I d$.

143. NORWEGIAN MINISTRY OF ForEIGN AFFAIRS, THE NORWEgIAN GOVERNMENT'S HigH NORTH STRATEGY 6 (2006), available at http://www.regjeringen.no/upload/UD/Vedlegg/strategien.pdf.

144. NAMMINERSORNERULLUTIK OQARTUSSAT UDENRIGSMINISTERIET [MINISTRY OF FOREIGN AFFAIRS (OF DENMARK) AND THE HOME RULE GOVERNMENT (OF GREENLAND)], ARKTIS I EN BRYDNINGSTID: FORSLAG TIL STRATEGI FOR AKTIVITETER I DET ARKTISKE OMRÅDE [THE ARCTIC AT A TIME OF TRANSITION: PROPOSED STRATEGY FOR ACTIVITIES IN THE ARCTIC REGION] (2008), available at http://www.um.dk/NR/rdonlyres/962AFDC2-30CE-412D-B7C7070241C7D9D8/0/ARKTISK_STRATEGI.pdf.

145. Statement on Canada's Arctic Foreign Policy: Exercising Sovereignty and Promoting Canada's Northern Strategy Abroad, FOREIGN AFF. \& INT'L TRADE CAN. (last updated on Mar. 10, 2011), http://www.international.gc.ca/polarpolaire/canada_arctic_foreign_policy_booklet-la_politique_etrangere_du_canada_ pour_arctique_livret.aspx?lang=eng.

146. Osnovy gosudarstvennoi politiki Rossiiskoi Federatsii v Arktike na period do 2020 goda $i$ dal'neishuiu perspektivu [Fundamentals of State Policy of the Russian Federation in the Arctic for the Period up to 2020 and Beyond], http://www.scrf.gov.ru/documents/98.html (last modified June 26, 2010) (confirmed by the President of the Russian Federation, D. Medvedev on Sept. 18, 2008).

147. Directive on Arctic Region Policy, 45 WEEKLY COMP. PRES. DOC. 47 (Jan. 12, 2009), available at http://frwebgate.access.gpo.gov/cgibin/getdoc.cgi?dbname $=2009$ presidential_documents\&docid=pd19ja09_txt-11.pdf. 
legal framework governing the Arctic issues is the law of the sea, which is reflected in the [1982 Convention]." 148

Thirdly, a maritime delimitation agreement concluded between Norway and the Russian Federation and was signed on September 15, $2010 .^{149}$ The joint statement by the respective Foreign Ministers announcing the breakthrough on April 27, 2007 already referred to the Ilulissat Declaration, ${ }^{150}$ which indicates that both parties considered the 1982 Convention the basis on which the parties reached this delimitation agreement. This conclusion was also stressed by the Foreign Ministers in a column in the French newspaper Le Monde in early October 2010, commenting on the recently reached delimitation agreement. ${ }^{151}$ In this respect, the concluding remarks of a recent study on this agreement are worth mentioning:

The Norway-Russia delimitation treaty will probably have few concrete implications for other existing and future maritime delimitation disputes. Nevertheless, the treaty confirms the statements of the five Arctic coastal states (The United States, Canada, Demark, Russia, and Norway) in the 2008 Ilulissat Declaration that the Arctic Ocean and its adjacent seas are subjected to a comprehensive legal framework through the law of

148. Ian G. Brosnan, Thomas M. Leschine \& Edward L. Miles, Cooperation or Conflict in a Changing Arctic?, 42 OCEAN DEV. \& INT'L L. 173, 175 (2011).

149. Treaty Between the Kingdom of Norway and the Russian Federation Concerning Maritime Delimitation and Cooperation in the Barents Sea and the Arctic Ocean, Nor.-Russ., Sept. 15, 2010, available at http://www.regjeringen.no/ upload/SMK/Vedlegg/2010/avtale_engelsk.pdf.

150. Joint Statement on Maritime Delimitation and Cooperation in the Barents Sea and the Arctic Ocean, para. 2, Nor.-Russ., Apr. 27, 2007, available at http://www.regjeringen.no/upload/UD/Vedlegg/Folkerett/030427_english_4.pdf.

151. Segeï Lavrov \& Jonas Gahr Store, Gestion de l'Arctique : la coopération doit l'emporter sur la confrontation [The Management of the Arctic : Cooperation Must Prevail Over Confrontation], LE MONDE (Fr.), Oct. 6, 2010, at 19. The only subtitle of the article "Base juridique indispensable" (Crucial Legal Basis) focuses on the 1982 Convention. Even though other agreements can possibly supplement the 1982 Convention, the latter represents the primary legal basis on which future negotiations regarding cooperation on Arctic related matters will have to be based. Id. 
432 California Western International LaW Journal [Vol. 41

the sea and their commitment to settle overlapping claims in an orderly way ${ }^{152}$

All these novel elements, in other words, seem to confirm the gist of this Article. The only caveat seems to be a dissonant stream in Russian scholarship opining that Russia should not make a second submission to the Commission on the Limits of the Continental Shelf because Part XI of the 1982 Convention, entitled "The Area," is not applicable to the Arctic. ${ }^{153}$ No matter how interesting a detailed analysis of this strand of argumentation might appear from a legal point of view, it will suffice for present purposes to simply mention it here as a concluding remark of this post-script, while postponing a more substantive analysis for the time being.

152. Tore Henriksen \& Geir Ulfstein, Maritime Delimiatation in the Arctic: The Barents Sea Treaty, 42 OCEAN DEV. \& INT'L L. 1, 10 (2011).

153. See, e.g., Ivan V. Bunik, Alternative Approaches to the Delimitation of the Arctic Continental Shelf, 2008 INT'L ENERGY L. REV. 114, 125. 